\title{
HUMANISTIC APPROACH TOWARDS EDUCATION OF PRESCHOOL CHILDREN WITH DEVELOPMENTAL SPEECH AND LANGUAGE DISORDERS
}

ABORDAGEM HUMANÍSTICA PARA A EDUCAÇÃO DE CRIANÇAS PRÉ-ESCOLARES COM DISTÚRBIOS DE DESENVOLVIMENTO DE FALA E LINGUAGEM

ENFOQUE HUMANISTA HACIA LA EDUCACIÓN DE NIÑOS EN EDAD PREESCOLAR CON TRASTORNOS DEL DESARROLLO DEL HABLA Y EL LENGUAJE

\author{
Voitovych Oksana ${ }^{1}$ \\ Kozliuk Olha ${ }^{2}$ \\ Kosarieva Oksana ${ }^{3}$ \\ Marchuk Galyna ${ }^{4}$ \\ Stepanova Olga ${ }^{5}$
}

\begin{abstract}
Changing approaches towards education of preschool children with developmental speech and language disorders occurs due to systemic pressure from government policy, which includes the development of inclusive education, the promotion of multidisciplinary cooperation in the development of policies and educational practices. Differentiation, personalization and integration of children with special educational needs are trends that indicate the humanization of education. Based on the analysis of scientific publications on the issues of therapy (treatment) and education of preschool children with developmental speech and language disorders for 2000-2019, key trends in education have been identified. The academic paper summarizes the experience of involving parents in the treatment of children. The importance of increasing parents' awareness concerning the peculiarities of children with developmental speech and language disorders has been identified. The effectiveness of family-centered practice in education compared to usual practice has been proven. It has been determined that the humanistic approach should include the principle of involvement of all subjects of education of children with developmental speech and language disorders. Family-centered practice is a form of humanistic approach to education, where there is a division of responsibilities and reducing the burden on preschool teachers in the upbringing and education of such children. The features of a humanistic approach to education determine the individual approach to therapy and education. This approach is complemented
\end{abstract}

\footnotetext{
${ }^{1}$ Rivne State University of Humanities. Rivne, Ukraine.

${ }^{2}$ Rivne State University of Humanities. Rivne, Ukraine.

${ }^{3}$ Rivne State University of Humanities. Rivne, Ukraine.

${ }^{4}$ Rivne State University of Humanities. Rivne, Ukraine.

${ }^{5}$ Rivne State University of Humanities. Rivne, Ukraine.
} 
by differentiated and personalized approaches. It has been determined that home speech sound disorder treatment is effective due to the formation of the natural environment, which contributes to the formation of positive relationships between children developmental speech and language disorders and parents.

Keywords: Education of children with developmental speech and language disorders (DSLD), developmental speech and language disorders, preschool children, education of preschool children, humanistic approach.

Resumen: A mudança de abordagens em relação à educação de crianças pré-escolares com distúrbios de desenvolvimento de fala e linguagem ocorre devido à pressão sistêmica da política governamental, que inclui o desenvolvimento da educação inclusiva, a promoção da cooperação multidisciplinar no desenvolvimento de políticas e práticas educacionais. A diferenciação, personalização e integração de crianças com necessidades educacionais especiais são tendências que indicam a humanização da educação. Com base na análise de publicações científicas sobre as questões de terapia (tratamento) e educação de crianças pré-escolares com distúrbios do desenvolvimento de fala e linguagem para 20002019, as principais tendências na educação foram identificadas. $O$ artigo acadêmico resume a experiência de envolver os pais no tratamento de crianças. Foi identificada a importância de aumentar a conscientização dos pais sobre as peculiaridades das crianças com distúrbios de desenvolvimento de fala e linguagem A eficácia da prática centrada na família na educação em comparação com a prática usual foi comprovada. Foi determinado que a abordagem humanística deve incluir o princípio do envolvimento de todas as disciplinas da educação de crianças com distúrbios do desenvolvimento da fala e da linguagem. A prática centrada na família é uma forma de abordagem humanística da educação, onde há uma divisão de responsabilidades e redução da carga sobre os professores da pré-escola na educação e educação dessas crianças. As características de uma abordagem humanística da educação determinam a abordagem individual da terapia e da educação. Esta abordagem é complementada por abordagens diferenciadas e personalizadas. Determinou-se que o tratamento domiciliar dos distúrbios sonoros da fala é eficaz devido à formação do ambiente natural, que contribui para a formação de relações positivas entre os distúrbios da fala e da linguagem no desenvolvimento das crianças e os pais.

Palabras clave: Educação de crianças com distúrbios do desenvolvimento da fala e da linguagem (DSLD), distúrbios do desenvolvimento da fala e da linguagem, crianças pré-escolares, educação de crianças préescolares, abordagem humanística.

Resumo: El cambio de enfoques hacia la educación de los niños en edad preescolar con trastornos del desarrollo del habla y el lenguaje se produce debido a la presión sistémica de la política gubernamental, que incluye el desarrollo de la educación inclusiva, la promoción de la cooperación multidisciplinaria en el desarrollo de políticas y prácticas educativas. La diferenciación, personalización e integración de los niños con necesidades educativas especiales son tendencias que indican la humanización de la educación. Sobre la base del análisis de publicaciones científicas sobre los problemas de la terapia (tratamiento) y la educación de niños en edad preescolar con trastornos del desarrollo del habla y el lenguaje para 20002019, se han identificado tendencias clave en la educación. El artículo académico resume la experiencia de involucrar a los padres en el tratamiento de los niños. Se ha identificado la importancia de aumentar la conciencia de los padres sobre las peculiaridades de los niños con trastornos del desarrollo del habla y el lenguaje. Se ha demostrado la eficacia de la práctica educativa centrada en la familia en comparación con la práctica habitual. Se ha determinado que el enfoque humanista debe incluir el principio de participación de todos los sujetos de la educación de los niños con trastornos del desarrollo del habla y del lenguaje. La práctica centrada en la familia es una forma de enfoque humanista de la educación, donde hay una división de responsabilidades y se reduce la carga de los maestros de preescolar en la crianza y educación de estos niños. Las características de un enfoque humanista de la educación determinan el enfoque individual de la terapia y la educación. Este enfoque se complementa con enfoques diferenciados y personalizados. Se ha determinado que el tratamiento del trastorno de los sonidos del habla en el hogar 
es eficaz debido a la formación del entorno natural, que contribuye a la formación de relaciones positivas entre los niños con trastornos del desarrollo del habla y el lenguaje y los padres

Palavras-chave: eEducación de niños con trastornos del desarrollo del habla y el lenguaje (DSLD), trastornos del desarrollo del habla y del lenguaje, niños en edad preescolar, educación de niños en edad preescolar, enfoque humanista.

\section{INTRODUCTION}

Education of preschool children with developmental speech and language disorders (DSLD) is one of the priority subjects of research in the scientific literature. Education can be considered as an element of therapy of children with developmental speech and language disorders, which includes: solving problems with disorders and skills, achieving the development of functionally significant skills, supporting adults in order to form a favorable environment for education (Morgan, L., et al, 2019). Education of children with DSLD identifies opportunities to further improve the functional problems of speech (Fox, A.V., Dodd, B. and Howard, D., 2002) and ensures satisfaction of their special needs (Coad, J, Harding, S, Hambly, H, et al., 2020). Improperly chosen approaches and methods of education can lead to an increase in the level of serious general problems in communication (from $13 \%$ to $17 \%$ ) (McAllister, L., et al., 1993).

Due to the underdeveloped awareness of children with DSLD from general motor development, lower level of abilities (Verbal, Quantitative, Perceptual / Performance, and Memory), different way of thinking and speaking (Morgan, RL, Dawson, B. and Kerby, D., 1992), the approach to education should be humanistic (Müürsepp, I., et al, 2009). A humanistic approach to education improves the functional skills of children with DSLD over a certain period of time (Hidecker, M.J.C., et al, 2017), provides an increase in the ability of preschool children to communication and integration into the society (ThomasStonell, N. L., et al, 2010). Children with DSLD have special needs to develop speech, language and communication skills (Wren, Y., Harding, S., Goldbart, J. and Roulstone, S., 2018). In the process of education, namely therapy and diagnosis, "cognitive-linguistic and production approaches" are most commonly used (Wren, Y., Harding, S., Goldbart, J. and Roulstone, S., 2018).

"Effective speech sound discrimination at preschool age is known to be a prerequisite for the development of language skills and later literacy acquisition" (Kuuluvainen, S., et al, 2016). Therefore, the study of the problems and features of therapy, education and their effects is given much attention by scientists (Roulstone, S., Glogowska, M., Enderby, P., \& Peters, T. J., 1999). Education determines the prognosis of the results of solving the problems of children with DSLD.

The goal of the investigation involves the formation of features of a humanistic approach to the education of preschool children with developmental speech and language disorders.

The outlined goal has identified the basic objectives of the investigation:

1. To conduct an analysis of studies based on the results of using a humanistic approach to the education of preschool children with developmental speech and language disorders.

2. To formulate the basic principles and features of using a humanistic approach to the education of preschool children with developmental speech and language disorders.

\section{LITERATURE REVIEW.}

The approach to the education of preschool children with developmental speech and language disorders depends on various factors. One of the factors is the severity of developmental speech and 
language disorders and the type of disorders, and accordingly - the needs of the child (Morgan, L., et al, 2019). The following categories of speech disorders are possible, namely: "articulation/phonology, receptive language, expressive language and pragmatics, hearing, stuttering, and voice" (Okalidou, A. and Kampanaros, M., 2001). Children with developmental speech and language disorders are characterized by a more complex type of temperament that determines their behavior (Prior, M., et al, 2011). Adaptation of children in the educational environment is more difficult (Prior, M., et al, 2011). This determines the need to choose an approach to their education.

The next group of factors includes the quality of children's relationships with the teacher, parents and other children, their behavior in the society. The positive quality of children's relations with teachers and parents is connected with the improvement of relations of preschool children in the educational environment (preschool educational institutions). Positive quality of relations means a low level of conflict and a high degree of proximity (Rhoad-Drogalis, A., et al., 2018). "In general, the parents proved more effective than preschool teachers in remediating the child's speech" (Dodd, B., \&Barker, R., 1990). Recent studies suggest the use and integration of automated speech analysis (ASA) tools to modify speech of children with disabilities (McKechnie, et al, 2018).

Factors influencing the education of preschool children with developmental speech and language disorders are a set of "perinatal, medical and environmental variables" that determine "speech and language outcomes" in the future. The level of education of parents is an additional factor in the effectiveness of education and the level of humanization of education (McAllister, L., et al., 1993; RhoadDrogalis, A., et al., 2018).

Recent studies have focused on a mixed approach to the treatment of preschool children with developmental speech and language disorders. The author notes the need to choose the ways and methods of therapy and education depending on the needs of preschool children (Morgan, L., et al, 2019). Herewith, it is important to note that "children's communication skills concerned more parents and educators than other aspects of development" (McLeod, S., et al, 2018). That is, parents and educators are more concerned about the communication skills of preschool children than "behavior, social-emotional, school readiness, receptive language, self-help, fine motor and gross motor skills" (McLeod, S., et al, 2018). This is a matter of concern due to the low level of awareness of both parents and teachers about the real needs of children and due to the shifting emphasis in the education, upbringing and treatment of children.

Approaches to the education of preschool children with developmental speech and language disorders are changing due to systemic pressure from public policy, which includes the development of inclusive education, the promotion of multidisciplinary cooperation in development of policies and educational practices. (Lindsay, G., et al, 2002). Approaches to professional practice of education and work with preschool children are also changing (Lindsay, G., et al, 2002). These approaches involve the transition from clinical to general working conditions of professionals dealing with preschool children with developmental speech and language disorders. Studies prove the need for application of direct approaches to the treatment of preschool children with developmental speech and language disorders to ensure the safety and effectiveness of correction (Unicomb, R., Hewat, S., Spencer, E., \& Harrison, E., 2017).

The roles and responsibilities of teachers, parents and speech therapists in the treatment and education of preschool children with developmental speech and language disorders are also changing. The effectiveness of education is ensured by a combination of the following methods of work, namely: cooperation with individuals or groups of children; joint classroom planning; "speech and language therapist input" in curricula; time, spent on information exchange, planning and evaluation of educational outcomes; cooperation of speech therapists and educators who participate in training 
sessions; curricula; "formal remit for speech and language therapists to work within the context of curricula" (Reid, J., et al, 2005).

\section{DATA AND METHODS}

The study is based on the analysis of scientific publications for 2000-2019. The databases Wiley Online Library and Tandfonline, which contains research on the subject matter of preschool children's developmental speech and language disorders have been used in the study. The following key words have been used to search for research: preschool children education, preschool children's developmental speech and language disorders, preschool children language disorders, language skills and literacy of preschool children, speech, language and communication skills, developmental speech and language disorders, education, humanistic approach to education, humanistic approach to preschool education.

The search for studies has been conducted in magazines that have the highest Impact factor (Table 1) according to the Journal of Citation Reports Web of Science Core Collection. Magazines belong to the following categories: Rehabilitation, Audiology \& Speech-Language Pathology, Linguistics, Social Sciences, General. In total, for the period 2000-2019, the magazines published 120 issues of the International Journal of Language \& Communication Disorders and 120 issues of the International Journal of Speech-Language Pathology, which contained a total of 1680 publications on developmental speech and language disorders in 2000-2019.

Table 1. Characteristics of research sources

\begin{tabular}{|c|c|c|c|c|c|}
\hline \multirow[t]{2}{*}{ Journal } & \multirow{2}{*}{$\begin{array}{l}\text { Impact } \\
\text { factor }\end{array}$} & \multicolumn{4}{|c|}{ ISI Journal Citation Reports, 2018} \\
\hline & & $\begin{array}{l}\text { Audiology \& } \\
\text { Speech- } \\
\text { Language } \\
\text { Pathology }\end{array}$ & Linguistics & Rehabilitation & $\begin{array}{l}\text { Rehabilitation } \\
\text { (Social Science) }\end{array}$ \\
\hline $\begin{array}{l}\text { International } \\
\text { Journal of } \\
\text { Language \& } \\
\text { Communication } \\
\text { Disorders }\end{array}$ & 1.504 & $14 / 26$ & $44 / 184$ & $35 / 65$ & $32 / 69$ \\
\hline $\begin{array}{l}\text { International } \\
\text { Journal of Speech- } \\
\text { Language } \\
\text { Pathology }\end{array}$ & 1.280 & $18 / 26$ & $55 / 184$ & $42 / 65$ & $39 / 69$ \\
\hline
\end{tabular}

Source: the author's research.

The basic criteria for selecting publications were the subject matters of the investigation: developmental speech and language disorders of preschool children and approaches to education, therapy of preschool children with developmental speech and language disorders. Search by key words (Table 2) was performed using filters in the Wiley Online Library database: years (2000-2019), key words or key phrases, journal (magazine). The results of the investigation have been reflected in Table 2 . The results of the investigation have been repeated, that is, they contained the same studies by different key words (Figure 1-2). 
Table 2. Information on the processing of the investigation

\begin{tabular}{|l|l|l|}
\hline Number of articles depend on Key words & \multicolumn{2}{|c|}{ Search Results } \\
\cline { 2 - 4 } & $\begin{array}{l}\text { International Journal of } \\
\text { Language } \\
\text { Communication } \\
\text { Disorders }\end{array}$ & $\begin{array}{c}\text { International } \\
\text { Journal of Speech- } \\
\text { Language } \\
\text { Pathology }\end{array}$ \\
\hline preschool children education & 317 & 132 \\
\hline preschool children speech disorders, & 349 & 156 \\
\hline preschool children language disorders & 340 & 156 \\
\hline language skills and literacy of preschool children & 147 & 71 \\
\hline speech, language and communication skills & 991 & 675 \\
\hline developmental speech and language disorders & 1027 & 752 \\
\hline education, approach to education & No results & 506 \\
\hline approach to preschool education & No results & 98 \\
\hline preschool education & 265 & 132 \\
\hline Source: the author's research & & \\
\hline
\end{tabular}

The results of the investigation were an intermediate stage. Qualitative analysis was conducted to select publications that met the basic objectives of the study - to identify modern approaches to the education of preschool children with developmental speech and language disorders.

Figure 1. The results of the investigation of publications by key words "preschool children speech disorders"

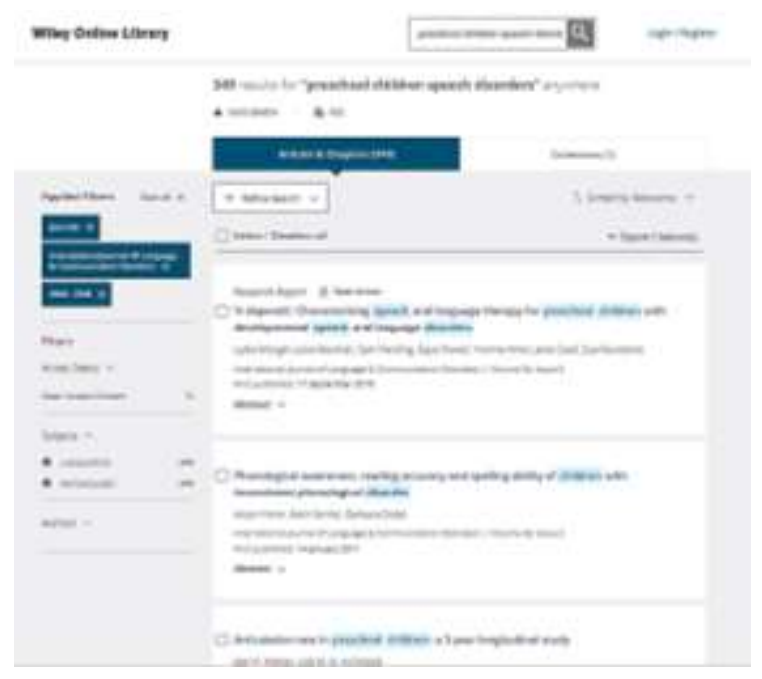


Source: the author's research.

Figure 2. The results of the investigation of publications by key words "speech, language and communication skills"



Source: the author's research.

As a result, publications were selected where the results of education of preschool children and approaches to education, therapy of preschool children with developmental speech and language disorders were partially or fully disclosed and highlighted.

\section{RESULTS AND DISCUSSION.}

Children with developmental speech and language disorders are actively involved in the formation of their own identity. Improper approaches to education of such children lead to the assignment of different labels that "have portrayed them in negative ways" (Lyons, R. \& Roulstone, S., 2017). For example, the emphasis on the development of communication skills eliminates other important problems of such children (McLeod, S., et al, 2018). Therefore, the choice of approach to the education of preschool children with developmental speech and language disorders should be humanistic. It is important for parents to take responsibility for education, upbringing and treatment of preschool children with developmental speech and language disorders. The direct approach to treatment, proposed by Unicomb, R., Hewat, S., Spencer, E., \& Harrison, E. (2017) (Table 3), shows the effectiveness of parental intervention in therapy.

Table 3. Direct approach to education proposed by Unicomb, R., Hewat, S., Spencer, E., \& Harrison, E. (2017)

\begin{tabular}{|l|l|}
\hline Approach & Approach details \\
\hline $\begin{array}{l}\text { Direct approach } \\
\text { to education }\end{array}$ & Direct, behavioural treatment \\
\hline $\begin{array}{l}\text { Conditions of } \\
\text { education and } \\
\text { therapy }\end{array}$ & $\begin{array}{l}\text { Treatment is delivered to parents who conduct daily therapy at home with their child in their } \\
\text { natural environment. A key component of the treatment is the parent's delivery of verbal } \\
\text { contingencies to their child during structured practice sessions and, subsequently, in natural } \\
\text { conversations. }\end{array}$ \\
\hline
\end{tabular}




\begin{tabular}{|l|l|l|l|l}
\hline $\begin{array}{l}\text { Home speech } \\
\text { sound disorder } \\
\text { treatment }\end{array}$ & $\begin{array}{l}\text { Complete daily home practice treatment is initially delivered for 10-15 min in structured } \\
\text { conversations. Home practice for the SSD was individualised depending on the nature of } \\
\text { participants' SSD and treatment approach/es, and recommended to be around } 10 \text { min } \\
\text { duration. }\end{array}$ \\
\hline Results & $\begin{array}{l}\text { Analysis of the primary outcome measure, \%SS, for stuttering revealed that four of the five } \\
\text { participants showed statistically significant improvements in their fluency levels from pre- } \\
\text { treatment to posttreatment. Analysis of the primary outcome for SSD, PCC, revealed that all } \\
\text { five participants showed statistically significant improvement from pre-treatment to } 12 \\
\text { months post commencement of treatment. This occurred across both sampling contexts, } \\
\text { single-word naming test and connected speech. }\end{array}$ \\
\hline
\end{tabular}

Source: Unicomb, R., Hewat, S., Spencer, E., \& Harrison, E. (2017).

McKean, K., Phillips B., \& Thompson, A. (2012) studying the "family-centered model (FCP) of care in pediatric speech-language pathology" prove that "greater parental responsibility for clinic therapy tasks and two home visits" more children in the FCP group improved on the Renfrew Action Picture Test than the usual practice (UP) group. FCP in contrast to UP includes other methods of treatment of children (Table 4).

Table 4. Intervention schedule

\begin{tabular}{|c|c|c|}
\hline $\begin{array}{l}\text { Week of } \\
\text { therapy }\end{array}$ & Usual practice & Family-centred practice \\
\hline 1 & $\begin{array}{l}\text { Parent group education } \\
\text { session } \\
\text { Individual goal-setting } \\
\text { session }\end{array}$ & $\begin{array}{l}\text { Parent group education session } \\
\text { Individual goal-setting session }\end{array}$ \\
\hline $2-6$ & $\begin{array}{l}\text { Individual clinic-based } \\
\text { therapy } 1 \text { session/week } \\
\text { Home program }\end{array}$ & $\begin{array}{l}\text { Individual clinic-based therapy } 1 \text { session/week Home program } \\
\text { Home visit by SLP in week } 4\end{array}$ \\
\hline $7-9$ & Home program & Home program \\
\hline 10 & $\begin{array}{l}\text { Review session to discuss } \\
\text { progress }\end{array}$ & Review session to discuss progress \\
\hline $11-14$ & $\begin{array}{l}\text { Individual clinic-based } \\
\text { therapy } 1 \text { session/week }\end{array}$ & $\begin{array}{l}\text { Individual clinic-based therapy } 1 \text { session/week Home program } \\
\text { Home program Home visit by SLP in Week } 11\end{array}$ \\
\hline
\end{tabular}

Source: McKean, K., Phillips B., \& Thompson, A. (2012).

Although the authors McKean, K., Phillips B., \& Thompson, A. (2012) have not revealed significant differences between groups of children in therapy based on FCP and (UP) (Table 4), nevertheless involvement of parents in the treatment process affected the level awareness of parents about the state of developmental speech and language disorders of their children. This solves the problem of parents' awareness of "behavior, social-emotional, school readiness, receptive language, self-help, fine motor and gross motor skills" of children with developmental speech and language disorders (McLeod, S., et al, 2018). In fact, the involvement of parents in the process of therapy can increase the level of education and awareness of parents, which affects the education and upbringing in long-term perspective. According to point of view of Rhoad - Drogalis, A., et al., (2018), parental awareness and education are a significant factor influencing the effectiveness of therapy and parenting. Therefore, the humanistic approach should include the principle of involvement of all subjects of education of children with developmental speech and 
language disorders. This means sharing responsibility and reducing the burden on the teachers in the process of education of such children.

Table 5. Between-group comparison of Goal Attainment Scale and Measures of Process of Care postintervention

\begin{tabular}{|c|c|c|c|c|c|}
\hline & $\begin{array}{l}\text { Family-centred } \\
\text { practice, M (SD) }\end{array}$ & $\begin{array}{l}\text { Usual } \\
\text { practice, M } \\
\text { (SD) }\end{array}$ & $\begin{array}{l}\text { Difference } \\
\text { between } \\
\text { means (SE) }\end{array}$ & $95 \% \mathrm{Cl}$ & $\begin{array}{l}p- \\
\text { value }\end{array}$ \\
\hline $\begin{array}{l}\text { Goal Attainment Scale- } \\
\text { Average score, n } 20\end{array}$ & $0.59(0.80)$ & $0.32(1.02)$ & $0.27(0.41)$ & $-0.59,114$ & 0.511 \\
\hline $\begin{array}{l}\text { Measures of Processes of } \\
\text { Care- } \\
\text { Enabling } \\
\text { \&partnership, n } 19\end{array}$ & $6.39(0.052)$ & $6.26(0.62)$ & $0.13(0.27)$ & $-0.43,0.69$ & 0.636 \\
\hline $\begin{array}{l}\text { Measures of Processes of } \\
\text { Care- Providing general } \\
\text { information, } n 10\end{array}$ & $5.44(1.05)$ & $4.38(1.00)$ & $1.05(0.67)$ & $-0.48,2.59$ & 0.152 \\
\hline $\begin{array}{l}\text { Measures of Processes of } \\
\text { Care- Providing specifi c } \\
\text { information about child, n } 19\end{array}$ & $6.03(0.55)$ & $5.44(0.71)$ & $0.59(0.29)$ & $-0.02,1.20$ & 0.057 \\
\hline $\begin{array}{l}\text { Measures of Processes of } \\
\text { Care- } \\
\text { \&comprehensive care, n } 19\end{array}$ & $6.35(0.51)$ & $6.29(0.63)$ & $0.06(0.27)$ & $-0.50,0.62$ & 0.815 \\
\hline $\begin{array}{l}\text { Measures of Processes of } \\
\text { Care- } \\
\text { Respectful } \\
\text { \&supportive care, } \mathrm{n} 20\end{array}$ & $6.66(0.43)$ & $6.42(0.56)$ & $0.24(0.22)$ & $-0.23,0.71$ & 0.304 \\
\hline
\end{tabular}

Source: McKean, K., Phillips B., \& Thompson, A. (2012).

In the practice of foreign countries, specialists involve parents in the treatment process of children with developmental speech and language disorders. "Speech-language pathologists (SLPS) either always or usually involved parents, suggesting that they understood the importance of family involvement in services provided" (Singh, S. J., Chan M. Y. \& Rusli Y. A., 2016). The individual approach to therapy and education is the most applied one. This approach is complemented by differentiated and personalized approaches (Lindner, K. T., Alnahdi, G. H., Wahl, S., Schwab, S., 2019). This means the humanization of education and upbringing of children with developmental speech and language disorders. Children with severe developmental speech and language disorders are subject to a greater level of differentiation and a more individual approach, while children with mild forms of developmental speech and language disorders need to take into account their special educational needs.

In addition to teachers, SLPs also call for close cooperation with families to establish a common goal and objectives, mutual understanding and an organized approach to education of children with developmental speech and language disorders (McKean, Phillips, \& Thompson, 2012; Nijhuis et al., 2007). SLPs should: (a) recognize the family as the client and not the individual child; (b) establish a parentprofessional relationship; (c) involve parents in decisions about education of children with developmental speech and language disorders, (d) allow parents to choose their level of involvement, and (e) empower families (Watts Pappas, McLeod, McAllister, \& McKinnon, 2008). In recent years, there has been a growing emphasis on family-oriented practices in the provision of services to children with developmental speech and language disorders (for instance, McKean et al., 2012; Watts Pappas et al., 2008). However, the focus on parental involvement requires more detailed research due to the lack of scientific justification for such practices in education and therapy. Models of care with parent involvement include the parent-as-therapist aide model, in which parents participate in the provision of home-based activities developed by the clinician 
but are generally not included in decision-making about their child's intervention (Watts Pappas et al., 2008).

Table 6. SLP practices during treatment

\begin{tabular}{|c|c|c|c|c|c|c|c|}
\hline $\begin{array}{l}\text { Components Service } \\
\text { models and team } \\
\text { collaboration }\end{array}$ & $\begin{array}{l}\text { Never } \\
\text { (\%) }\end{array}$ & $\begin{array}{l}\text { Seldom } \\
\text { (\%) }\end{array}$ & $\begin{array}{l}\text { Sometimes } \\
\text { (\%) }\end{array}$ & $\begin{array}{l}\text { Usually } \\
\text { (\%) }\end{array}$ & $\begin{array}{l}\text { Always } \\
\text { (\%) }\end{array}$ & C & $\begin{array}{l}\text { Combination } \\
\text { of "usually" } \\
\text { and "always" }\end{array}$ \\
\hline Individual therapy & 0 & 0 & 2,7 & 8,1 & 89,2 & $\mathrm{HC}$ & 97.3 \\
\hline Group therapy & 0 & 16.2 & 54.1 & 21.6 & 8.1 & $M C$ & 29.7 \\
\hline $\begin{array}{l}\text { Consultative model } \\
\text { (provide } \\
\text { recommendations or } \\
\text { train teachers in } \\
\text { schools) }\end{array}$ & 38.9 & 13.9 & 33.3 & 8.3 & 5.6 & IC & $13 . .9$ \\
\hline $\begin{array}{l}\text { Multidisciplinary } \\
\text { model }\end{array}$ & 26.3 & 29.0 & 34.2 & 10.5 & $0 .$. & IC & 10.5 \\
\hline
\end{tabular}

C, consistency; HC, highly consistent; MC, moderately consistent; IC, inconsistent practice across clinicians. Source: Singh, S. J., Chan M. Y. \& Rusli Y. A., (2016).

The FCP group participants' goals are often focused on the participant being understood or being more confident within specific settings or with particular family members, for example (McKean et al., 2012):

1. Other friends and family will understand the child better.

2. His mother, father and brother will understand the child more easily in long stories.

3. Parents will be able to correct the child's speech and the child will feel comfortable to have a go.

The parent/carer is a core member of the treating team. Cooperation with other health professionals during evaluation and treatment was infrequent. It has been revealed that it is inconsistent in all treatment programs for children with developmental speech and language disorders, which has been also noted in other local studies (Amar, 2008; Mustaffa Kamal et al., 2012). Teamwork practices do not meet current best practice guidelines, where SLPs involve not only families but also other health professionals in the treatment process (Nijhuis et al., 2007). According to a study conducted by Amar (2008), rehabilitation hospital services for children with developmental speech and language disorders in Malaysia are characterized by low integration, leading to a lack of implementation of a multidisciplinary service delivery model. In addition, heavy workload can be a deterrent to active collaboration with other professionals (Ahmad, 2010; Sharma 2008).

\section{CONCLUSION.}

Recent trends in state policies concerning the development of inclusion have influenced approaches to the education of preschool children with developmental speech and language disorders. As a result, a mixed approach to the treatment of preschool children with developmental speech and language disorders is gaining ground and the use of direct approaches to the treatment of preschool children with developmental speech and language disorders in order to ensure the safety and effectiveness of correction. Additional effects of education are provided by a combination of efforts of parents and teachers. The importance of parents' responsibility for education and treatment of preschool children with developmental speech and language disorders has been scientifically proven. The family-centered model 
of education enhances parental responsibility and greater awareness. Emphasis in education is shifting from the use of traditional methods of education to the formation of positive relationships between parents and children. This academic paper proves that the features of a humanistic approach are the principle of involvement of all subjects of education of children with developmental speech and language disorders. This means sharing responsibilities and reducing the burden on teachers in the process of education of such children. Herewith, the individual approach to therapy and education is the most applied one. This approach is complemented by differentiated and personalized approaches. This means the humanization of the education of children with developmental speech and language disorders. Children with severe developmental speech and language disorders are subject to a greater level of differentiation and a more individual approach, while children with mild forms of developmental speech and language disorders need to take into account their special educational needs.

\section{REFERENCES}

Ahmad, K. (2010). Discharging patients: A perspective from speech-language pathologists working in public hospitals in Malaysia. International Journal of Speech-Language Pathology, 12(4), 317-319.

Amar, H. S. S. S. (2008). Meeting the needs of children with disability in Malaysia. Med J Malaysia, 63(1), 1.

Brito, C. D. A., \& Nunes, C. P. (2020). The intensification of teaching work in the context of the commercialization of higher education in Brazil. Journal of Research and Knowledge Spreading, 1(1), $1-17$.

Coad, J, Harding, S, Hambly, H, et al. (2020), Perspectives of preschool children in England with speech and language needs in the development of evidence-based activities. Child Care Health Dev. 2020; 46: 283- 293. https://doi.org/10.1111/cch.12746

Dodd, B., \&Barker, R. (1990) The Efficacy of Utilizing Parents and Teachers as Agents of Therapy for Children with Phonological Disorders, Australian Journal of Human Communication Disorders, 18:1, 2945, DOI: 10.3109/asI2.1990.18.issue-1.03

Dias, A. F., Cardoso, H. de M., Santos, A. L. dos, Menezes, C. A. A., \& Rios, P. P. S. (2017). Schooling and subversions of gender. Revista Tempos e Espaços em Educação, 10(22), 83-92.

Ebrahimi, M. A. (2020). Cultural value of translation of proverbs and synopsis. Journal of Research and Knowledge Spreading, 1(1), 1-10.

Fox, A.V., Dodd, B. and Howard, D. (2002), Risk factors for speech disorders in children. International Journal of Language \& Communication Disorders, 37: 117-131. doi:10.1080/13682820110116776

Fullagar, S. (2019). A physical cultural studies perspective on physical (in)activity and health inequalities: the biopolitics of body practices and embodied movement. Revista Tempos e Espaços em Educação, 12(28), 63-76.

Hidecker, M.J.C., Cunningham, B.J., Thomas-Stonell, N., Oddson, B. and Rosenbaum, P. (2017), Validity of the Communication Function Classification System for use with preschool children with communication disorders. Dev Med Child Neurol, 59: 526-530. doi:10.1111/dmcn.13373

Kuuluvainen, S., Alku, P., Makkonen, T., Lipsanen, J. and Kujala, T. (2016), Cortical speech and non-speech discrimination in relation to cognitive measures in preschool children. Eur J Neurosci, 43: 738-750. doi:10.1111/ejn.13141 
Lindner, K. T., Alnahdi, G. H., Wahl, S., Schwab, S. (2019). Perceived Differentiation and Personalization Teaching Approaches in Inclusive Classrooms: Perspectives of Students and Teachers. Frontiers in Education 4 (58). doi:10.3389/feduc.2019.00058.

Lindsay, G., Soloff, N., Law, J., Band, S., Peacey, N., Gascoigne, M. and Radford, J. (2002), Speech and language therapy services to education in England and Wales. International Journal of Language \& Communication Disorders, 37: 273-288. doi:10.1080/13682820210137204

Lyons, R. \& Roulstone, S. (2017) Labels, identity and narratives in children with primary speech and language impairments, International Journal of Speech-Language Pathology, 19:5, 503518, DOI: $\underline{10.1080 / 17549507.2016 .1221455}$

McAllister, L., Masel, C., Tudehope, D., O'Callaghan, M., Mohay, H. and Rogers, Y. (1993), Speech and language outcomes in preschool-aged survivors of neonatal intensive care. International Journal of Language \& Communication Disorders, 28: 383-394. doi:10.3109/13682829309041472

McKean, K., Phillips B., \& Thompson, A. (2012) A family-centred model of care in paediatric speech-language pathology, International Journal of Speech-Language Pathology, 14:3, 235246, DOI: $\underline{10.3109 / 17549507.2011 .604792}$

McKechnie, et al, (2018) Automated speech analysis tools for children's speech production: A systematic literature review, International Journal of Speech-Language Pathology, 20:6, 583598, DOI: $10.1080 / 17549507.2018 .1477991$

McLeod, S., et al, (2018) Preschool children's communication, motor and social development: Parents' and educators' concerns, International Journal of Speech-Language Pathology, 20:4, 468482, DOI: $\underline{10.1080 / 17549507.2017 .1309065}$

Morgan, L., Marshall, J., Harding, S., Powell, G., Wren, Y., Coad, J. and Roulstone, S. (2019), 'It depends': Characterizing speech and language therapy for preschool children with developmental speech and language disorders. International Journal of Language \& Communication Disorders, 54: 954-970. doi: $10.1111 / 1460-6984.12498$

Morgan, R.L., Dawson, B. and Kerby, D. (1992), The performance of preschoolers with speech/language disorders on the McCarthy Scales of Children's Abilities. Psychol. Schs., 29: 11-17. doi:10.1002/1520-6807(199201)29:1<11::AID-PITS2310290103>3.0.CO;2-Z

Mustaffa Kamal, R. M., Ward, E., \& Cornwell, P. (2012). Dysphagia management practices among speechlanguage pathologists in Malaysia. Asia Pacific Journal of Speech, Language and Hearing, 15(2), 111128.

Müürsepp, I., Ereline, J., Gapeyeva, H. and Pääsuke, M. (2009), Motor performance in 5-year-old preschool children with developmental speech and language disorders. Acta Pædiatrica, 98: 1334-1338. doi:10.1111/j.1651-2227.2009.01294.x

Nijhuis, B. J., Reinders-Messelink, H. A., de Ble'court, A. C., Olijve, W. G., Groothoff, J. W., Nakken, H., \& Postema, K. (2007). A review of salient elements defining team collaboration in paediatric rehabilitation.Clinical rehabilitation, 21(3), 195-211.

Okalidou, A. and Kampanaros, M. (2001), Teacher perceptions of communication impairment at screening stage in preschool children living in Patras, Greece. International Journal of Language \& Communication Disorders, 36: 489-502. doi:10.1080/13682820110089399

Prior, M., Bavin, E., Cini, E., Eadie, P. and Reilly, S. (2011), Relationships between language impairment, temperament, behavioural adjustment and maternal factors in a community sample of preschool 
children. International Journal of Language \& Communication Disorders, 46: 489-494. doi:10.1111/j.1460-6984.2011.00003.x

Reid, J., et al, (2005), The role of the speech and language therapist in the education of children with special educational needs. International Journal of Language \& Communication Disorders, 30: 534-545. doi:10.1111/j.1460-6984.1995.tb01750.x

Rhoad-Drogalis, A., Justice, L.M., Sawyer, B.E. and O'Connell, A.A. (2018), Teacher-child relationships and classroom-learning behaviours of children with developmental language disorders. International Journal of Language \& Communication Disorders, 53: 324-338. doi:10.1111/1460-6984.12351

Roulstone, S., Glogowska, M., Enderby, P., \& Peters, T. J. (1999). Issues to consider in the evaluation of speech and language therapy for preschool children. Child: Care, Health and Development, 25(2), 141155. doi:10.1046/j.1365-2214.1999.25220119.x

Sharma, S. (2008). Speech pathology in the Asia-Pacific region: Speech pathology in Malaysia. Acquiring Knowledge in Speech, Language and Hearing, 10, 62-64.

Santos, I. T. R., Barreto, D. A. B., \& Soares, C. V. C. O. (2020). Formative assessment in the classroom: the dialogue between teachers and students. Journal of Research and Knowledge Spreading, 1(1), 1-14.

Singh, S. J., Chan M. Y. \& Rusli Y. A. (2016) Practise patterns of Malaysian speech-language pathologists in managing children with speech and language delay/disorder, International Journal of SpeechLanguage Pathology, 18:6, 560-570, DOI: 10.3109/17549507.2016.1139624

Thomas-Stonell, N. L., Oddoson, B., Robertson, B. and Rosenbaum, P.L. (2010), Development of the FOCUS (Focus on the Outcomes of Communication Under Six), a communication outcome measure for preschool children. Developmental Medicine \& Child Neurology, 52: 47-53. doi: $\underline{10.1111 / \text { i.1469- }}$ 8749.2009.03410.x

Unicomb, R., Hewat, S., Spencer, E., \& Harrison, E. (2017) Evidence for the treatment of co-occurring stuttering and speech sound disorder: A clinical case series, International Journal of SpeechLanguage Pathology, 19:3, 251-264, DOI: 10.1080/17549507.2017.1293735

Watts Pappas, N. W., McLeod, S., McAllister, L., \& McKinnon, D. H. (2008). Parental involvement in speech intervention: A national survey. Clinical Linguistics and Phonetics, 22, 335-344.

Wren, Y., Harding, S., Goldbart, J. and Roulstone, S. (2018), A systematic review and classification of interventions for speech-sound disorder in preschool children. International Journal of Language \& Communication Disorders, 53: 446-467. doi:10.1111/1460-6984.12371 


\section{ABOUT THE AUTHORS}

\section{Voitovych Oksana}

Assistant Professor, Rivne State University of Humanities, Educational Sciences Faculty, Department of Pedagogy and Psychology. Rivne, Ukraine.

E-mail: oks1812@i.ua

ORCID: https://orcid.org/0000-0002-1506-7959

\section{Kozliuk Olha}

Candidate of Pedagogical Sciences (PhD), Associate Professor, Rivne State University of Humanities, Educational Sciences Faculty, Department of Pedagogy and Psychology. Rivne, Ukraine.

E-mail: pratsia87@ukr.net

ORCID: https://orcid.org/0000-0002-6948-327X

\section{Kosarieva Oksana}

Candidate of Pedagogical Sciences (PhD), Associate Professor, Rivne State University of Humanities, Educational Sciences Faculty, Department of Pedagogy and Psychology. Rivne, Ukraine.

Email: judah15@i.ua

ORCID: https://orcid.org/0000-0001-6905-905X

\section{Marchuk Galyna}

Assistant Professor, Rivne State University of Humanities, Educational Sciences Faculty, Department of Pedagogy and Psychology. Rivne, Ukraine.

E-mail: anastas555@i.ua

ORCID: https://orcid.org/0000-0002-4907-5340

\section{Stepanova Olga}

Candidate of Philological Sciences (PhD), Associate Professor, Rivne State University of Humanities, Educational Sciences Faculty, Department of Pedagogy and Psychology. Rivne, Ukraine.

ORCID: https://orcid.org/0000-0001-6063-5110

E-mail: romanenkorom@i.ua 